\title{
Adopt-A-Store: An Innovative \& Immersive Experiential Pedagogy for Visual Merchandising Design
}

\author{
Victoria Brown and Cathy Nowicki, High Point University
}

\begin{abstract}
Through its multidimensional exploration of individual learning processes and different learning styles, experiential learning theory (ELT) offers a compelling basis for the development and improvement of academic curricula (Kolb, 1984; Kolb and Kolb, 2008). Experiential learning has long been cited as a common pedagogical approach emphasizing personal and active engagement with, and reflection on, a real world problem or challenge that is inherently complex (Svanström, Lozano-Garcia, and Rowe, 2008). Grauerholz and Bubriski-McKenzie (2012) found this exceptionally pertinent when studying marketplace consumption. Studies have shown that learning is a transformative process that occurs when students: engage in specific tasks, experiences from those tasks are considered and retained (imprinted), and this retention is confirmed and enhanced by testing and application within a similar context (Armstrong and LeHew, 2011). Retail Industry demand and educational institutional requirements for preparing and positioning graduates in a competitive job market identify Visual Merchandising and Fashion Merchandising curricula as "fertile ground" for implementation of this immersive learning model.
\end{abstract}

An experiential learning approach for an introductory Visual Merchandising studio project was considered ideal for its flexibility in allowing the learner to gain real life practical experience during a scenario which afforded personal choice in store selection, fostered attachment to an intended career path (Visual Merchandising, Fashion Merchandising, Store Design), and identified emergent evidence of student learning (experiential). This interactive experience required independent deployment of critical thinking, decision making, and problem solving skills, while the student made observations that stimulated new and/or enhanced learning through real-world immersion. Learning was self-directed, iterative, and shaped a personal conceptualization of what is truly important about "learning" retail skills.

Learning Objectives: The objectives of this project were: 1) to afford each student a uniquely individualized student experience through individual store choice, containing all aspects of retail visual merchandising design as proprietarily implemented by a local retailer identifying as a specific store "type", including: store purpose, merchandising and sales ideology, circulation layout, fixture choice and placement, lighting choice and placement, color scheme, store finish selection, security requirements, visual window display, and promotional display placement and

Published under a Creative Commons Attribution License (https://creativecommons.org/licenses/by/4.0/), which permits unrestricted use, distribution, and reproduction in any medium, provided the original work is properly cited.

ITAA Proceedings, \#76 - https: / /itaaonline.org 
purpose, 2) to enhance students' awareness and application of the principles and elements of design for customer behavioral modification and sales impact while creating aesthetic and attractive displays, and 3) to understand how the display design process facilitates store merchandising goals, and 4) to understand how branding is utilized for retail sales planning and selling.

Implementation: This exercise was incorporated into an introductory Visual Merchandising Studio as an eight- week project entitled "Adopt-A-Store". The class was comprised of third year students. Students were asked to select a soft or hard lines retailer within local driving distance of the university to "adopt" and partner with for all aspects of the project. Students first had to obtain permission from the store manager or owner to conduct the study, and then explain all methodologies of data collection requirements including site visits, taking photographs, customer behavioral observation, and employee interviews or surveys. Students were required to safeguard the store's proprietary information including management protocols and pricing strategies. They then pulled as-built dimensional measurements of the store in order to create an accurate floor plan, reflected ceiling plan (ceiling details and lighting), and front store entrance elevation which most often included display window locations. Additional deliverables for the project included analyzing: the retailer's target market demographics, fixture choice and purpose, signage design and placement, pricing and ticketing types, branding, and security systems. Students were also asked to design a customized point-of-purchase (POP) display that would be appropriate for that particular retailer and store location based upon research (programming) data collected. To best inform P.O.P design, students engaged in typical design process work including "mind mapping", the creation of storyboards, and mood board development in order to best understand the retailer's target customers and brand image.

Learning Outcomes: This project provided visual merchandising design and fashion merchandising students a unique opportunity to partner with and experience a real existing retail store of their choice (creating a feeling of "empathy / partnership" during the learning process), study and learn from daily retail operational planning and activities, observe the impact of design and managerial decisions on customer behaviors, and design a custom display fixture reflecting the design and purpose of the store to help contribute to store sales. Design process was intensive, reinforcing the importance of visual thinking and merchandising strategies from concept thru installation. Students determined which strategies worked best in their particular stores, based upon store size, product assortment, and target market demographics. Some students were permitted by the store manager to implement their own design strategies in the store during the partnership, magnifying the perceived benefit of the experiential learning model.

Published under a Creative Commons Attribution License (https://creativecommons.org/licenses/by/4.0/), which permits unrestricted use, distribution, and reproduction in any medium, provided the original work is properly cited.

ITAA Proceedings, \#76 - https://itaaonline.org 
Conclusions: Student feedback and quality of work suggest that this project provides a unique and valuable experience for students to experience and study store design and retailing decision making as conducted in the real-world while still in university. Students indicated that by physically going to the stores, conducting data gathering activities, and participating in conversations with management, they are exposed to and best comprehend merchandising decisions and practices that are either very successful or subject to revision. They can then utilize these lessons and resulting skill set in future studio projects and in practice after graduation.

\section{References:}

Armstrong, C.M. \& LeHew, M.L.A. (2011). Sustainable apparel product development: In search of a new dominant social paradigm for the field using sustainable approaches. Fashion Practice, 3(1), 29-62.

Grauerholz, L. \& Bubriski-McKenzie, A. (2012). Teaching about consumption: The "not buying it" project. Teaching Sociology, 40(4), 332-348.

Kolb, David. (1984). Experiential learning: Experience as the source of learning and development. Prentice Hall, Upper Saddle River: NJ.

Kolb, A. Y., \& Kolb, D. A. (2009). The learning way: Meta-cognitive aspects of experiential learning. Simulation \& gaming, 40(3), 297-327.

Svanström, M., Lozano-García, F. J., \& Rowe, D. (2008). Learning outcomes for sustainable development in higher education. International Journal of Sustainability in Higher Education, 9(3), 339-351.

Page 3 of 3

(c) 2019 The author(s). Published under a Creative Commons Attribution License (https://creativecommons.org/licenses/by/4.0/), which permits unrestricted use, distribution, and reproduction in any medium, provided the original work is properly cited.

ITAA Proceedings, \#76 - https: / /itaaonline.org 